\title{
Antioxidant and Antidiabetic Activities of Mempening (Lithocarpus bancanus) Leaves
}

\author{
Muhammad Almurdani' ${ }^{1}$, Adel Zamri' ${ }^{1}$, Titania T. Nugroho' ${ }^{1}$, Jasril Karim ${ }^{1}$, Yum Eryanti ${ }^{1}$, Rudi Hendra ${ }^{1}$, Hilwan \\ Yuda Teruna ${ }^{1, *}$
}

Muhammad Almurdani', Adel

Zamri', Titania T. Nugroho', Jasril Karim ${ }^{1}$, Yum Eryanti' ${ }^{1}$, Rudi Hendra ${ }^{1}$, Hilwan Yuda Teruna, ${ }^{1, *}$

'Department of Chemistry, Faculty of Mathematics and Natural Sciences, Universitas Riau, Pekanbaru 28293, INDONESIA.

\section{Correspondence}

\section{Hilwan Yuda Teruna}

Department of Chemistry, Faculty of Mathematics and Natural Sciences, Universitas Riau, Pekanbaru 28293, Indonesia

E-mail: hyteruna@lecturer.unri.ac.id History

- Submission Date: 09-12-2019;

- Review completed: 02-01-2020;

- Accepted Date: 22-01-2020

DOI : 10.5530/pj.2020.12.52

Article Available online http://www.phcogj.com/v12/i2

\section{Copyright}

(C) 2020 Phcogj.Com. This is an openaccess article distributed under the terms of the Creative Commons Attribution 4.0 International license.

\begin{abstract}
Background: Lithocarpus bancanus or commonly called as mempening in Talang Mamak Tribe, Indonesia is a plant that is used as a traditional medicine. Objective: This study aim to evaluated antioxidant and antidiabetic activities of $L$. bancanus leaves extract. Material and Methods: The methanol extract was obtained by maceration of the leaves. The $n$-hexane, dichloromethane and ethyl acetate fractions were prepared by successive partition process of the methanol extract. Antioxidant activities were evaluated by various antioxidant assays, including DPPH (1,1-diphenyl-2-picrylhydrazyl), FRAP (ferric reducing antioxidant power), CUPRAC (cupric reducing antioxidant capacity), and ABTS (2,2'-azonobis 3-ethylbenzothiazoline-6-sulfonic acid) method. Total phenolics were estimated based on the Folin-Ciocalteu method, while, aluminum chloride methods were employed to estimate total flavonoids. Antidiabetic activies was determined by inhibiting the activity of $\alpha$-glucosidase method. Results: antioxidant activity assay against DPPH radical as well as the total phenolic and flavonoid content of $L$. bancanus leaves showed that the methanol extract possessed $I C_{50}$ value of $39.469 \pm 0.273 \mu \mathrm{g} / \mathrm{mL}$ with total phenol and flavonoid were $11.426 \pm 0.432 \mathrm{mg} \mathrm{GAE} / \mathrm{g}$ dry weight sample and $15.423 \pm 0.213 \mathrm{mg}$ QE/g respectively. The FRAP, CUPRAC and ABTS values of methanol extract were $3494.302 \pm 0.45626665 .501 \pm 5.940$ and $2857.977 \pm 0.715$ $\mu \mathrm{M} T E / g$ dry weight sample respectively. Antidiabetic activity of methanol extract with $\mathrm{IC}_{50}$ value of $30.565 \pm 0.331 \mu \mathrm{g} / \mathrm{mL}$. Conclusion: It could be concluded that leaves of $L$. bancanus have antioxidant and antidiabetic properties.
\end{abstract}

Key words: Antioxidant; Antidiabetic; Lithocarpus bancanus; Talang Mamak Tribe.

\section{INTRODUCTION}

Diabetes mellitus is the common serious metabolic disorder due to disturbance of carbohydrate, lipid and protein metabolism. It is characterized by hyperglycaemia resulting from insulin resistance or decreased production of insulin by the $\beta$-cells of the pancreas. Approximately $90 \%$ of all cases of diabetes in developed and developing countries are type-2 diabetes. ${ }^{1,2}$ Hyperglycemia is found to increase the production of free radicals that are associated with long-term damage, dysfunction, and failure of various organs, especially eyes, kidneys, nerves, hearts, and blood vessels. Several other factors such as hyperlipidaemia and enhanced oxidative stress play a major role in diabetes. The development of diabetes and progression of complications are usually associated with oxidative stress which is as a result of overexpression of reactive oxygen species (ROS) or free radicals. Free radicals are generated during autoxidation of glucose in diabetes mellitus resulting in oxidative stress. ROS is involved in the process of signal transduction in the pancreatic $\beta$-cells and has the potential to regulate glucose-stimulated insulin secretion. However, insulin secretion can reduce when excessive ROS synthesis is produced by elevated glucose or fatty acid oxidation. ${ }^{3,4}$

Traditional medicine is gaining so much interest recently due to their multiple modes of actions with minimal adverse effects in humans. Medicinal plant are rich source of secondary metabolites used in various therapies, including diabetes mellitus. Thus, considering the high Indonesia biodiversity, it is essential to explore potential plant species, including $L$. bancanus (mempening). This species belongs to Fagaceae family found in the Talang Mamak tribe in Kelayang District, Indragiri Hulu Regency, Riau Province. It is usually used by the peoples as a medicine to treat pain and inflammation. Some species of this genus have been previously reported to contain various secondary metabolites, including terpenoids, steroids and flavonoids as the major components. Likewise, bioactivities from the genus have been evaluated including antioxidants, antidiabetic, anticancer, antimicrobial and other activities. ${ }^{5-8}$ In regard to explore antidiabetic agent from Talang Mamak medicinal plants ${ }^{9}$, we reported the antioxidant and antidiabetic activity of $L$. bancanus leaves extract and fractions.

\section{MATERIAL AND METHOD}

\section{Chemical reagents}

DPPH (1,1-diphenyl-2- picryl hydrazyl), gallic acid, quercetin, ascorbic acid, Trolox ${ }^{\otimes}$ TPTZ (2, 4, 6-tripydyl-s-triazine), neocuproine (Nc), $\alpha$-glucosidase enzyme and $p$-nitrophenyl- $\alpha$-Dglucopyranoside ( $p$-NPG) substrate from Sigmaaldrich Chemical Co (Singapore). Folin-Ciocalteu,

Cite this article: Almurdani M, Zamri A, Nugroho TT, Karim J, Eryanti Y, Hendra R, et al. Antioxidant and Antidiabetic Activities of Mempening (Lithocarpus bancanus) Leaves. Pharmacog J. 2020;12(2):328-34. 
$\mathrm{Na}_{2} \mathrm{CO}_{3}, \mathrm{NaNO}_{2}, \mathrm{AlCl}_{3}, \mathrm{NaOH}, \mathrm{CuCl}_{2} .2 \mathrm{H}_{2} \mathrm{O} 10 \mathrm{mM}$, neocuproine $(\mathrm{Nc}), \mathrm{K}_{2} \mathrm{~S}_{2} \mathrm{O}_{8}$, organic solvents p.a ( $n$-hexane, dichloomethane, ethyl acetate and methanol from Merck (Germany).

\section{Collection of plant material}

Samples was collected from Kelayang (Bukit Tiga Puluh National Park (TNBT) of Indragiri Hulu Regency, Riau Province and identification of sample plants was carried out in the Department of Biology, Faculty of Mathematics and Natural Sciences, University of Riau. Samples were dried and finely ground and stored at $4^{\circ} \mathrm{C}$ until analysis.

\section{Extraction}

Dried L. bancanus leaves $(100 \mathrm{~g})$ were ground into powder and then macerated for 48 hour followed by ultrasound for 1 hour and the macerates were collected and concentrated with a rotary evaporator at $50^{\circ} \mathrm{C}$. Methanol extract were fractionated with $n$-hexane, dichloromethane and ethyl acetate respectively. Each fraction were evaporated to get extracts.

\section{DPPH radical scavenging activity assay}

Antioxidant activity assay was carried out by using DPPH method (1,1-diphenyl-2- picryl hydrazyl) by the standard method, with a slight modification. ${ }^{10-12}$ Samples with a finally concentration of $1000 \mu \mathrm{g} / \mathrm{mL}$ were diluted by two fold dilution method $(1000-31.25 \mu \mathrm{g} / \mathrm{mL})$ in 96 well clear polystyrene microplate. A total of $50 \mu \mathrm{L}$ of sample was added with $80 \mu \mathrm{L}$ of DPPH $100 \mu \mathrm{g} / \mathrm{mL}$ then incubated for 30 minutes in a dark place. Absorbance were measured by microplate reader (Berthold, Germany) at $520 \mathrm{~nm}$. The same method were conducted for ascorbic acid and quercetin as positive control.

The \% Inhibition value is calculated by the following formula:

\% Inhibition $=\left(\left(\mathrm{A}_{0}-\mathrm{A}_{\mathrm{s}}\right)\right) / \mathrm{A}_{0} \times 100$

Where $\boldsymbol{A}_{0}$ represents the absorbance of the DPPH radical solution without sample while $\boldsymbol{A}_{s}$ represents the absorbance of the sample with DPPH radical solution. A graph of inhibition percentages (I\%) versus concentrations of the sample was plotted to provide value of $\mathrm{IC}_{50}$.

\section{Determination of total phenolic content (TPC)}

Determination of the total phenolic sample was carried out by using the Folin-Ciocalteu method. ${ }^{13-16}$ Gallic acid was used as a standard. A total of $100 \mu \mathrm{L}$ of sample, gallic acid and blank were each mixed with $50 \mu \mathrm{L}$ of the Folin-Ciocalteu reagent $0.25 \mathrm{~N}$ in 96-well microplate. After 5 minutes, $100 \mu \mathrm{L} \mathrm{Na}_{2} \mathrm{CO}_{3} 7.5 \%$ (w v) was added. The mixture was incubated for 30 minutes in a dark place at room temperature before absorbance was measured at a wavelength of $765 \mathrm{~nm}$ by microplate reader. The total phenolic content is expressed as milligrams of equivalent gallic acid per gram dry matter of sample (mgGAE/g) throught the calibration curve gallic acid. Linearity range of calibration curve was $10-50 \mu \mathrm{g} / \mathrm{mL}(\mathrm{y}=0.016 \mathrm{x}+0.0081, r=0.992)$.

\section{Determination of total flavonoids content (TFC)}

Determination of the total flavonoid content of extracts was carried out by using the colorimetric method of aluminum chloride with quercetin as a standard. ${ }^{13} \mathrm{~A}$ total of $50 \mu \mathrm{L}$ samples, quercetin and blanks were each mixed with $10 \mu \mathrm{L} \mathrm{NaNO}_{2} 5 \%(\mathrm{w} / \mathrm{v}), 10 \mu \mathrm{L} \mathrm{AlCl}_{3} 10 \%(\mathrm{w} / \mathrm{v})$ in 96 well micoplates. After 5 minutes $100 \mathrm{~mL}$ of $1 \mathrm{M} \mathrm{NaOH}$ was added. The mixture was added with $30 \mathrm{~mL}$ of distilled water and the mixture was incubated in a dark place at room temperature for 30 minutes. Absorbance of the mixture was measured at a wavelength of $510 \mathrm{~nm}$ by microplate reader. The total content of flavonoids is expressed as milligrams of equivalent quarsetin per gram dry matter of sample $(\mathrm{mgQE} / \mathrm{g})$. Linearity range of calibration curve was $10-50 \mu \mathrm{g} / \mathrm{mL}(\mathrm{y}=$
$0.0162 \mathrm{x}+0.0755, r=0.999)$.

\section{Ferric reducing antioxidant power assay (FRAP)}

Antioxidant activity was measured with FRAP according to the method with Trolox as standard. ${ }^{17}$ FRAP reagents was made from 0.2 $\mathrm{M}$ acetate buffer solution ( $\mathrm{pH}$ 3.6), TPTZ solution (2, 4, 6-tripydyl-striazine) $10 \mathrm{mM}$ in $40 \mathrm{mM} \mathrm{HCl}$ and $20 \mathrm{mM} \mathrm{FeCl}_{3} \cdot 6 \mathrm{H}_{2} \mathrm{O}$ solution were prepared and then the solution was mixed with ratio 10: 1: 1 . Some $100 \mu \mathrm{L}$ of sample was added to 96 -well clear polystyrene microplates which contained $100 \mu \mathrm{L}$ of FRAP reagent. The mixture was incubated for 30 minutes in a dark place at room temperature. The absorbance of sample was measured at wavelength of $595 \mathrm{~nm}$ by microplate reader and calculated as micromolar of Trolox equivalent per gram of dry weight (mg TE/g dry weight) and using the Trolox as standard curve. Linearity range of calibration curve was $2-10 \mu \mathrm{M} / \mathrm{mL}(\mathrm{y}=0.0641 \mathrm{x}+$ $0.0644, r=0.991)$.

\section{Cupric reducing antioxidant capacity assay (CUPRAC)}

Antioxidant activity was measured using the CUPRAC analysis. ${ }^{18}$ Some $50 \mu \mathrm{L}$ of $\mathrm{CuCl}_{2}$. 2 $\mathrm{H}_{2} \mathrm{O} 10 \mathrm{mM}, 50 \mu \mathrm{L}$ Neocuproine (Nc) $7.5 \mathrm{mM}$ and $50 \mu \mathrm{L}$ ammonium acetate buffer were added to 96 well- clear polystyrene microplates which contained $100 \mu \mathrm{L}$ of samples, standard and blank. Then, distilled water was added up to $300 \mu \mathrm{L}$. The mixture was incubated for 30 minutes in a dark place at room temperature and the absorbance was read at $450 \mathrm{~nm}$ by microplate reader and calculated as micromolar of Trolox equivalent per gram of dry weight (mg TE / $\mathrm{g}$ dry weight) and using Trolox as standard curve. Linearity range of calibration curve was $20-100 \mu \mathrm{M} / \mathrm{mL}(\mathrm{y}=0.0073 \mathrm{x}+0.1274 r=0.999)$.

\section{2,2'-azonobis 3-ethylbenzothiazoline-6-sulfonic acid assay (ABTS)}

Antioxidant activity was carried out with the ABTS method. ${ }^{19}$ ABTS reagents was prepared by dissolving $0.077 \mathrm{~g}$ ABTS powder in 10 $\mathrm{ml}$ of distilled water. $10 \mathrm{ml}$ of ABTS solution was reacted with $10 \mathrm{ml}$ of $\mathrm{K}_{2} \mathrm{~S}_{2} \mathrm{O}_{8}(5 \mathrm{mM})$ and was saved in a dark place at room temperature for 16 hours to produce ABTS radical cation. The solution was diluted with distilled water to obtain an absorbance of 1.00 at a wavelength of $734 \mathrm{~nm}$. Some $100 \mu \mathrm{L}$ of ABTS ${ }^{+}$solution was added to 96 well clear polystyrene microplates which contained $200 \mu \mathrm{L}$ of sample, standard, and blank. The mixture was incubated for 30 minutes in a dark place at room temperature. The absorbance of the sample was measured at a wavelength $734 \mathrm{~nm}$ by microplate reader (Berthold, Germany). and the results were calculated as micromolar of Trolox equivalent per gram of dry weight (mg TE/g dry weight) using the Trolox as standard curve. Linearity range of calibration curve was $2-10 \mu \mathrm{M} / \mathrm{mL}(\mathrm{y}=0.0738 \mathrm{x}+$ $0.0473, r=0.999)$.

\section{Antidiabetic activity assay}

The antidiabetic test used a method of inhibiting the activity of $a$-glucosidase enzyme with $p$-NPG as a substrate by the standard method, with a slight modification..$^{20-22}$ The sample was diluted by the two fold dilution method of concentration $1000-31.25 \mu \mathrm{g} / \mathrm{mL}$. A total of $10 \mu \mathrm{L}$ of DMSO $\left(\mathrm{B}_{0}\right)$ and $10 \mu \mathrm{L}$ of sample $\left(\mathrm{S}_{0}\right)$ were added with $50 \mu \mathrm{L}$ of $\mathrm{pH} 7$ phosphate buffer, $25 \mu \mathrm{L}$ of p-NPG $20 \mathrm{mM}$ and $10 \mu \mathrm{L}$ of DMSO $\left(\mathrm{B}_{1}\right)$ and $10 \mu \mathrm{L}$ of sample $\left(\mathrm{S}_{1}\right)$ with $50 \mu \mathrm{L}$ of phosphate buffer $\mathrm{pH} 7.25$ $\mu \mathrm{L}$ p-NPG $20 \mathrm{mM}$ and $25 \mu \mathrm{L}$ a-glucosidase $0.2 \mathrm{U} / \mathrm{mL}$ were mixed in 96-well microplate and incubated for 30 minutes at $37^{\circ} \mathrm{C}$. The reaction was stopped by adding $100 \mu \mathrm{L}$ of $0.1 \mathrm{M} \mathrm{Na}_{2} \mathrm{CO}_{3}$ then absorbance was measured by microplate reader at a wavelength of $405 \mathrm{~nm}$.

The $\%$ Inhibition value is calculated by the following formula:

$$
\text { \% Inhibition }=\frac{\left(B_{1}-B_{0}\right)-\left(S_{1}-S_{0}\right)}{\left(B_{1}-B_{0}\right)} \times 100
$$


Where $\boldsymbol{B}_{\boldsymbol{0}}$ represents the absorbance without sample and enzyme, $\boldsymbol{B}_{1}$ represents the absorbance without sample and contain enzyme, $S_{0}$ represents the absorbance contain sample and without enzyme while $S_{0}$ represents the absorbance contain sample and enzyme. A graph of inhibition percentages (I\%) against concentrations of the sample was plotted to provide value of $\mathrm{IC}_{50}$.

\section{Statistical analysis}

All assays were carried out in triplicate and their results were expressed as mean \pm standard deviation. Data analysed by one - way ANOVA by using IBM SPSS statistics 20 (Version 20.0, IBM. Corp., U.S.A). The significance of difference was calculated by using Duncan's multiple range test, while Pearson correlation test was conducted to determine the correlation among variable. A $P<0.05$ were considered statistically significant levels. All measurements were carried triplicate.

\section{RESULT AND DISCUSSION}

\section{DPPH radical scavenging activity}

DPPH radical scavenging activity from L. bancanus leaves exibited various activity (Table 1). Methanol extract and ethyl acetate fraction showed high antioxidant activity with $\mathrm{IC}_{50}$ value of $39.469 \pm 0.273$ $\mu \mathrm{g} / \mathrm{mL}$ and $52.546 \pm 0.557$ respectively with no significantly different $(P<0.05)$ with quercetin. The $n$-hexane fraction showed no activity with $\mathrm{IC}_{50}$ values greater than $1000 \mu \mathrm{g} / \mathrm{mL}$ while the dichloromethane fraction exhibited moderate antioxidant activity with $\mathrm{IC}_{50}$ values of $334.464 \pm 0.361 \mu \mathrm{g} / \mathrm{mL}$. In this result showed that the solvent with high polarity exhibited high activity, and this might be due to the presence of flavonoids and phenolics.

\section{Total phenolic (TPC) and flavonoid content (TFC)}

The determination of TPC is based on the reduction of the phosphomolybdate-tungstate complex with its active center is Mo (VI) by phenolic compounds forming a blue product. ${ }^{18}$ Totcal phenolic content of extract and fraction of $L$. bancanus leave were differed significantly $(P<0.05)$ (Table 2$)$. Methanol extract and ethyl acetate fraction showed high TPC compared to $n$-hexane and dichloromethane fractions with value of $11.426 \pm 0.106$ and $6.525 \pm 0.188 \mathrm{mg} \mathrm{GAE} / \mathrm{g}$ dry weight sample, respectively. In order to determined TFC, the samples were reacted with $\mathrm{AlCl}_{3}$ to form a complex in the ortho hydroxy ketone group which gives a batochromic effect from flavonoid. ${ }^{23}$ The results showed that methanol extract and ethyl acetate fraction exhibited high TFC with value of $15.422 \pm 0.306$ and $9.144 \pm 0.138 \mathrm{mg} Q$ QE/dry weight sample, respectively $(\mathrm{p}<0.05)$

Flavonoids are diphenyl propanoids consisting of two of rings connected by chains with three of carbon atoms. The plants extracts contained phenolic and flavonoid compounds which showed effective antioxidant properties and could lower cellular oxidative stress. ${ }^{24}$ In this study, we reported correlation between the phenolic and flavonoid content with DPPH radical scavanging with coeficient correlation $(r)=$ 0.996 and 0.994 , respectively (Table 3 ) and it is in an agreement with Jacobo-Velazquez and coworkers. ${ }^{25}$

\section{Ferric reducing antioxidant power (FRAP)}

The FRAP method was used to measure the ability of antioxidants by reducing ferric in acidic conditions. Complex ferric-tripyridyltriazine ( $\mathrm{Fe}{ }^{+3}$-TPTZ) is reduced to form $\mathrm{Fe}^{+2}$ ( $\mathrm{Fe}^{+2}$-TPTZ) with maximum absorbance at $595 \mathrm{~nm} .{ }^{26}$ The results showed significanly different among the tested sampel $(P<0.05)$, however, the methanol extract and quercetin exhibited no sifnificantly different (Table 3).

\section{Cupric reducing antioxidant capacity (CUPRAC)}

In this assay, $\mathrm{Cu}$ (II) was reduced to $\mathrm{Cu}$ (I) by antioxidants. Neocuproin $(\mathrm{Nc})$ chromophore reagent reacts with $\mathrm{CuCl}_{2}$ to form complex $\mathrm{Cu}$ (I) $-\mathrm{Nc}$ at $\mathrm{pH} 7$ at a wavelength of $450 \mathrm{~nm}$, from bright blue to yellow-orange. ${ }^{27}$ The results showed that extract and fractions differed significantly $(P<0.05)$ (Table 3). The methanol extract and ethyl acetate fraction possessed activity with valueo of $26665.501 \pm 5.940$ and $15146.556 \pm 3.107 \mu \mathrm{M}$ TE/dry weight, respectively, and these results exibited high activity compared to $n$-hexane and dichloromethane fractions.

\section{2,2'-azonobis 3-ethylbenzothiazoline-6-sulfonic acid (ABTS)}

The ABTS (2,2'-azonobis 3-ethylbenzothiazoline-6-sulfonic acid) assay is based on the ability of antioxidants to capture the cation radical of ABTS. In this assay, the radical cation of ABTS is produced from ABTS oxidation by potassium persulfate $\left(\mathrm{K}_{2} \mathrm{~S}_{2} \mathrm{O}_{8}\right)$ which produces a greenish blue color. Color loss will occur when antioxidant compounds donate $\mathrm{H}$ atoms to the ABTS cation radical. ${ }^{27}$ The antioxidant activity of a sample in reducing ABTS cation radical compared to Trolox, and

Table 1. Antioxidant activity of $L$. bancanus leaves against DPPH radical.

\begin{tabular}{cc}
\hline Sample & $\mathrm{IC}_{50}(\mu \mathrm{g} / \mathrm{mL})$ \\
\hline$n$-Hexane fraction & $1151.808 \pm 17.458^{\mathrm{a}}$ \\
Dichloromethane fraction & $334.464 \pm 0,361^{\mathrm{b}}$ \\
Ethyl acetate fraction & $52.546 \pm 0.557^{\mathrm{c}}$ \\
Methanol extract & $39.469 \pm 0.273^{\mathrm{c}}$ \\
Quercetin & $40.063 \pm 1.604^{\mathrm{c}}$ \\
Ascorbic Acid & $11.043 \pm 0.154^{\mathrm{d}}$ \\
\hline
\end{tabular}

Note: Data expressed as mean \pm standard deviation $(n=3)$. Same letters in each column mean no significant difference $(P<0.05)$.

Table 2. Total phenolic and flavonoid content of $L$. bancanus leaves.

\begin{tabular}{ccc}
\hline Sample & $\begin{array}{c}\text { Total phenolic } \\
(\mathbf{m g ~ G A E} / \mathrm{g} \text { dry sample) }\end{array}$ & $\begin{array}{c}\text { Total flavonoid } \\
\text { (mg QE/g dry sample) }\end{array}$ \\
\cline { 2 - 3 }$n$-Hexane fraction & $0.472 \pm 0.241^{\mathrm{d}}$ & $0.463 \pm 0.110^{\mathrm{d}}$ \\
Dichloromethane fraction & $0.788 \pm 0.125^{\mathrm{c}}$ & $0.925 \pm 0.216^{\mathrm{c}}$ \\
Ethyl acetate fraction & $6.525 \pm 0.188^{\mathrm{b}}$ & $9.144 \pm 0.138^{\mathrm{b}}$ \\
Methanol extract & $11.426 \pm 0.106^{\mathrm{a}}$ & $15.422 \pm 0.306^{\mathrm{a}}$ \\
\hline
\end{tabular}

Note: Data expressed as mean \pm standard deviation $(n=3)$. Same letters in each column mean no significant difference $(P<0.05)$. GAE: Gallat acid equivalents, QE: Quercetin equivalents. 
they showed significantly different $(P<0.05)$ (Table 3$)$. The value of ABTS from methanol extract and ethyl acetate fraction were 2857.977 \pm 0.715 and $1402.082 \pm 0.371 \mu \mathrm{M} \mathrm{TE} /$ dry weight sample, respectively, and they exibited highest ABTS values compared to $n$-hexane and dichloromethane.

\section{Correlation analyses between phenolic and flavonoid} contents with antioxidant and Inhibitor a-glucosidase activities

Correlation analyses (Table 4) between phenolic and flavonoid content with antioxidant (DPPH, FRAP, CUPRAC, ABTS) and antidibetic (inhibitor $\alpha$-glucosidase) activities were performed. Extract and fraction of $L$. bancanus leaves exhibited significant $(P<0.01)$ linear corelations between TPC and TFC, TPC and $\mathrm{IC}_{50} \mathrm{DPPH}, \mathrm{TPC}$ and FRAP, TPC and CUPRAC, TPC and ABTS, and TPC and $\mathrm{IC}_{50}$ $\alpha$-glucosidase inhibitor. By comparing the correlation coeficient $(r)$ between TPC and CUPRAC exibited highest $r$ value $(r=1)$, followed by TPC and TFC $(r=0.999)$, TPC and ABTS $(r=0.997)$, TPC and FRAP $(\mathrm{r}=0.996)$, TPC and $\mathrm{IC}_{50} \alpha$-glucosidase inhibitor $(r=0.944)$ and TPC and $\mathrm{IC}_{50}$ DPPH $(r=0.944)$. There were linear correlation $(P<0.01)$ between TFC and CUPRAC, TFC and ABTS, TFC and FRAP, TFC and $\mathrm{IC}_{50} \alpha$-glucosidase and TFC and $\mathrm{IC}_{50} \mathrm{DPPH}$ with $r=0.999,0.994,0.993$, 0.955 and 0.739 , respectively.
Through these correlation analysis, the phenolic and flavonoid contents diplayed association with antioxidant activities (DPPH radical, FRAP, CUPRAC and ABTS) and antidiabetic activities. The results are consistent with those found by Sahreen who reported that there was existence of a strong relationship between phenolic and flavonoid contents and DPPH and FRAP, CUPRAC and ABTS radical scavenging. ${ }^{28}$

\section{Antidiabetic activity assay}

The $\alpha$-glucosidase enzyme is the enzyme which responsible for breaking down disaccharides and complex carbohydrates into glucose. Inhibition of this enzyme can delay the absorption of glucose in the digestive tract, and to prevent an increasing in blood glucose concentration after eating. ${ }^{29} \alpha$-glucosidase inhibition activity is one of method to determined antidiabetic acivity. The mechanism of this assay was observed by interfering with the carbohydrate hydrolysis process, inhibits the absorption of glucose and other monosaccharides. Inhibition of this enzyme can effectively to reduce the digestion of complex carbohydrates and their absorption, so as to reduce the increase in postprandilla glucose levels in diabetics. ${ }^{30}$ The antidiabetic activity results showed significantly different $(P<0.05)$, where methanol extract showed high activity followed by ethyl acetate fraction with $\mathrm{IC}_{50} 30.565 \pm 0.331 \mu \mathrm{g} / \mathrm{mL}, 44.901 \pm 0.128$ $\mu \mathrm{g} / \mathrm{mL}$, respectively. (Table 5). There are significant corrrelation between total phenolics and flavanoids and the activity $(P<0.01)$ with coeficient correlation $(r)=0.944$ and 0.955 (Table 4).

Table 3. Antioxidant activities (FRAP, CUPRAC and ABTS) of $L$. bancanus leave.

\begin{tabular}{cccc}
\hline Sample & FRAP & CUPRAC & ABTS \\
\cline { 2 - 4 } & $(\mu \mathrm{M} \mathrm{TE} / \mathrm{g}$ dry sample $)$ & $(\mu \mathrm{M}$ TE/g dry sample $)$ & $(\mu \mathrm{M}$ TE/g dry sample $)$ \\
\hline$n$-Hexane fraction & $126.508 \pm 0.996^{\mathrm{e}}$ & $380.082 \pm 0.544^{\mathrm{f}}$ & $77.517 \pm 0.776^{\mathrm{f}}$ \\
Dichloromethane fraction & $190.050 \pm 0.581^{\mathrm{d}}$ & $536.926 \pm 0.579^{\mathrm{e}}$ & $131.634 \pm 0.741^{\mathrm{e}}$ \\
Ethyl acetate fraction & $1695.239 \pm 0.372^{\mathrm{c}}$ & $15146.556 \pm 3.107^{\mathrm{d}}$ & $1402.082 \pm 0.371^{\mathrm{d}}$ \\
Methanol extract & $3494.302 \pm 0.456^{\mathrm{b}}$ & $26665.501 \pm 5.940^{\mathrm{b}}$ & $2857.977 \pm 0.715^{\mathrm{b}}$ \\
Quercetin & $3492.846 \pm 2.930^{\mathrm{b}}$ & $25848.774 \pm 5.940^{\mathrm{c}}$ & $2742.498 \pm 0.589^{\mathrm{c}}$ \\
Ascorbic Acid & $35220.782 \pm 0.674^{\mathrm{a}}$ & $28571.197 \pm 5.941^{\mathrm{a}}$ & $2911.909 \pm 0.889^{\mathrm{a}}$ \\
\hline
\end{tabular}

Note: Data expressed as mean \pm standard deviation $(n=3)$. Same letters in each column mean no significant difference $(P<0.05)$, TE: Trolox equivalents.

Table 4. Correlation between phenolic and flavonoid contents with antioxidant and antidiabetic (inhibitor $a$-glucosidase) activities of $L$. bancanus leaves.

\begin{tabular}{|c|c|c|c|c|c|c|c|}
\hline & TPC & TFC & $\mathrm{IC}_{50} \mathrm{DPPH}$ & FRAP & CUPRAC & ABTS & $\begin{array}{c}I_{50} \\
\text { a-glucosidase }\end{array}$ \\
\hline TPC & - & $0.999^{* *}$ & $0.730^{* *}$ & $0,996^{* *}$ & $1,000^{* *}$ & $0.997^{* *}$ & $0.944^{* *}$ \\
\hline TFC & & - & $0.739^{* *}$ & $0.993^{* *}$ & $0.999^{* *}$ & $0.994^{* *}$ & $0.955^{* *}$ \\
\hline $\mathrm{IC}_{50} \mathrm{DPPH}$ & & & - & $-0.697^{*}$ & $0.722^{* *}$ & $0.701^{*}$ & $0.844^{* *}$ \\
\hline FRAP & & & & - & $0.995^{* *}$ & $1,000^{* *}$ & $0.916^{* *}$ \\
\hline CUPRAC & & & & & - & $0.996^{* *}$ & $0.947^{* *}$ \\
\hline ABTS & & & & & & - & $0.920^{* *}$ \\
\hline$\frac{\mathrm{IC}_{50}}{\alpha \text {-glucosidase }}$ & & & & & & & - \\
\hline
\end{tabular}

${ }^{* *}$ Correlation is significant at the 0.01 level (2-tailed).

${ }^{\star}$ Correlation is significant at the 0.05 level (2-tailed).

Table 5. Antidiabetic (Inhibitor $\boldsymbol{\alpha}$-glucosidase) activity of $L$. bancanus leaves.

\begin{tabular}{cc}
\hline Sample & $\mathrm{IC}_{50}(\mu \mathrm{g} / \mathrm{mL})$ \\
\hline$n$-Hexane fraction & $116.607 \pm 1.379^{\mathrm{a}}$ \\
Dichloromethane fraction & $102.189 \pm 1.631^{\mathrm{b}}$ \\
Ethyl acetate fraction & $44.901 \pm 0.128^{\mathrm{c}}$ \\
Methanol extract & $30.565 \pm 0.331^{\mathrm{d}}$ \\
Acarbose & $18.173 \pm 0.122^{\mathrm{e}}$ \\
\hline
\end{tabular}

Note: Data expressed as mean \pm standard deviation $(n=3)$. Same letters in each column mean no significant difference $(P<0.05)$. 


\section{CONCLUSION}

The leaves extract and its $n$-hexane, dichloromethane and ethyl acetate fractions of $L$. bancanus showed high antioxidant and antidiabetic activities, especially ethyl acetate fraction and methanol extracts. It could be concluded that leaves of L. bancanus has antioxidant and antidiabetic properties.

\section{ACKNOWLEDGEMENTS}

Thanks to Ministry of Research, Technogy and Higher Education of the Republic of Indonesia for supporting this research through postgraduate grant research, Contract Number: 339/UN.19.5.1.3/ $\mathrm{PP} / 2018$.

\section{REFERENCES}

1. Mustafa SB, Mehmood Z, Akhter N, Kauser A, Hussain I, Rashid A, et al. Medicinal plants and management of diabetes mellitus: a review. Pak J Pharm Sci. 2016.29(5):1885-91

2. Hasimun P, Adnyana K. Alpha-glucosidase activity: implication for diabetes. In: Watson RR, Preedy VR, eds, Bioactive Food as Dietary Interventions for Diabetes. Elsivier, UK. 2019;387-93.

3. Newsholme P, Cruzat VF, Keane KN, Rodrigo Carlessi R, de Bittencourt PIH. Molecular mechanisms of ROS production and oxidative stress in diabetes. Biochemical Journal. 2016.473;4527-50.

4. Chikezie PC, Ojiako OA, Ogbuji AC. Oxidative stress in diabetes mellitus. International Journal of Biological Chemistry. 2015;9(3):92-109.

5. Sun Y, LiW, Liu Z. Preparative isolation, quantification and antioxidant activity of dihydrochalcones from Sweet Tea (Lithocarpus polystachyus Rehd.). Journal of Chromatography B. 2015;1002:372-8.

6. Dong H, Li M, Zhu F, Liu F, Huang J. Inhibitory potential of trilobatin from Lithocarpus polystachyus Rehd against $\alpha$-glucosidase and $\alpha$-amylase linked to type 2 diabetes. Food Chemistry. 2012;130(2):261-266.

7. Lin C, Wang L, Wang H, Fang S, Zhan Q, Yang L, et al. Lithocarpus Polystachyus rehd leaf aqueous extract inhibits human breast cancer growth in vitro and in vivo. Inhibits Human Breast Cancer Growth In Vitro and In Vivo. 2014;37-41.

8. Khan MRU, Kihara M, Omoloso AD. Antimicrobial activity of Lithocarpus celebicus. Fitoterapia. 2001;703-5

9. Ridhasya FE, Rahim N, Almurdani M, Hendra R, Teruna HY. Antidiabetic Constituents from Helminthostachys zeylanica (L) Hook (Ophioglossaceae). Pharmacognosy Journal. 2020.

10. Philip M. The use of the stable free radical diphenylpicryl-hydrazyl (DPPH) for estimating antioxidant activity. Songklanakarin Journal of Science and Technology. 2004;26:211-9.

11. Rodrigo S, Godoy HT. Antioxidant activity index (AAI) by the 2, 2-diphenyl-1picrylhydrazyl method. Food Chemistry. 2009;112:654-8.

12. Yao $Y$, Sang $W$, Zhou $M$, dan Ren G. Phenolic composition and antioxidant activities of 11 celery cultivars. Journal of Food Science. 2010;75(1):9-13

13. Bhanuz D, Ruamdee P, Poonnaimuang S, Mokmued K, Chunthorng-orn J. Antioxidant and antimicrobial activities of pogostemon cablin (Blanco) benth. Journal of Botany. 2017;1-6.
14. Wong JE, Muñiz DB, Aguilar P, Aguilar CN. microplate quantification of tota phenolic content from plant extracts obtained by conventional and ultrasound methods microplate quanti fi cation of total phenolic content from plan extracts obtained by conventional and ultrasound methods. Phytochemical Analisys. 2014;25(5):439-44.

15. Yu LL. Methods for antioxidant capacity estimation of wheat and wheat-based. In John Wiley \& Sons, Inc. 2018;118-72.

16. Zhang Q, Zhang J, Shen J, Silva A, Dennis DA, Barrow CJ. A simple 96-well microplate method for estimation of total polyphenol content in seaweeds. Journal of Applied Phycology. 2006;18(3):445-450.

17. Musa KH, Abdullah A, Jusoh K, dan Subramaniam V. Antioxidant activity of pinkflesh guava (Psidium guajava L.): effect of extraction techniques and solvents. Journal of Food Analytical Methods. 2011;4:100-7.

18. Apak R, Güçlü K, Demirata B, Özyürek M, Çelik SE, Beçtasoĝlu B, et al Comparative evaluation of various total antioxidant capacity assays applied to phenolic compounds with the CUPRAC assay. Molecules. 2007;12:1496-547.

19. Yao Y, Sang W, Zhou M, dan Ren G. Phenolic composition and antioxidant activities of 11 celery cultivars. Journal of Food Science. 2010;75(1):9-13.

20. Peyman S, Asghari B, Esmaeili MA, Dehghan H, Ghazi I. $\alpha$-glucosidase and $\alpha$-Amylase Inhibitory Effect and Antioxidant Activity of Ten Plant Extracts Traditionally Used in Iran for Diabetes. Journal of Medicinal Plants Research. 2013;7(6):257-66.

21. Sheng Z, Dai $H$, Pan $S$, Wang $H, H u Y, M a W$. Isolation and Characterization of an $\alpha$-glucosidase Inhibitor from Musa spp. (Baxijiao) Flowers. Molecules. 2014;19:10563-73.

22. Zhang L, Tu Z, Yuan T, Wang H, Xie X, Fu Z. Antioxidants and $\alpha$-glucosidase inhibitors from Ipomoea batatas leaves identified by bioassay-guided approach and structure-activity relationships. Food Chemistry. 2016;08:61-7.

23. Taie HAA, El-Mergawi R, dan Radwan S. Isoflavonoid, flavonoid, phenolic acid, and antioxidant activity of soybean seeds as affected by organic and bioorganic fertilization. Journal of Agricultural and Environmental Science. 2008;4(2):20713.

24. TyugTS, Prasad KN, dan Ismail A. Antioxidant capacity, phenolics and isoflavones in soybean by products. Journal of Food Chemistry. 2010;123:583-9.

25. Jacobo-Velazquez DA, dan Cisneros-Zevallos L. Correlation of antioxidant activity against phenolic content revisited: a new approach in data analysis for food and medicinal plants. Journal of Food Science. 2009;74(9):107-13.

26. Gil MI Fransisco A, Tomás-Barberán A, Hess-Pierce B, Holcroft DM, dan Kader AA. Antioxidant activity of pomegranate juice and its relationship with phenolic composition and processing. Journal of Agricultural and Food Chemistry. 2000;48:4581-9.

27. Prior R, Wu X dan Schaich K. Standardized methods for the determination of antioxidant capacity and phenolics in foods and dietary supplements. Journal of Agricultural and Food Chemistry. 2005;53:4290-302

28. Sahreen S, Khan MR, Khan RA. Evaluation of antioxidant activities of various solvent extracts of Carissa opaca fruits. Food Chemistry Journal. 2010;122(4):1205-11.

29. Chisholm-Burns MA, Schwinghammer TL, Wells BG, Malone PM, Kolesar JM, Dipiro JT. Pharmacotherapy, principles and practice. 2016. Mc Graw-Hill Companies. New York.

30. Shinde J, Taldone T, Barletta M, Kunaparaju N, Hu B, Kumar $\mathrm{S}$, et al. a -glucosidase inhibitory activity of Syzygium cumini (Linn.) Skeels seed kernel in vitro and in Goto-Kakizaki (GK) rats. Carbohydrate Research. 2008;343:1278-81. 


\section{GRAPHICAL ABSTRACT}

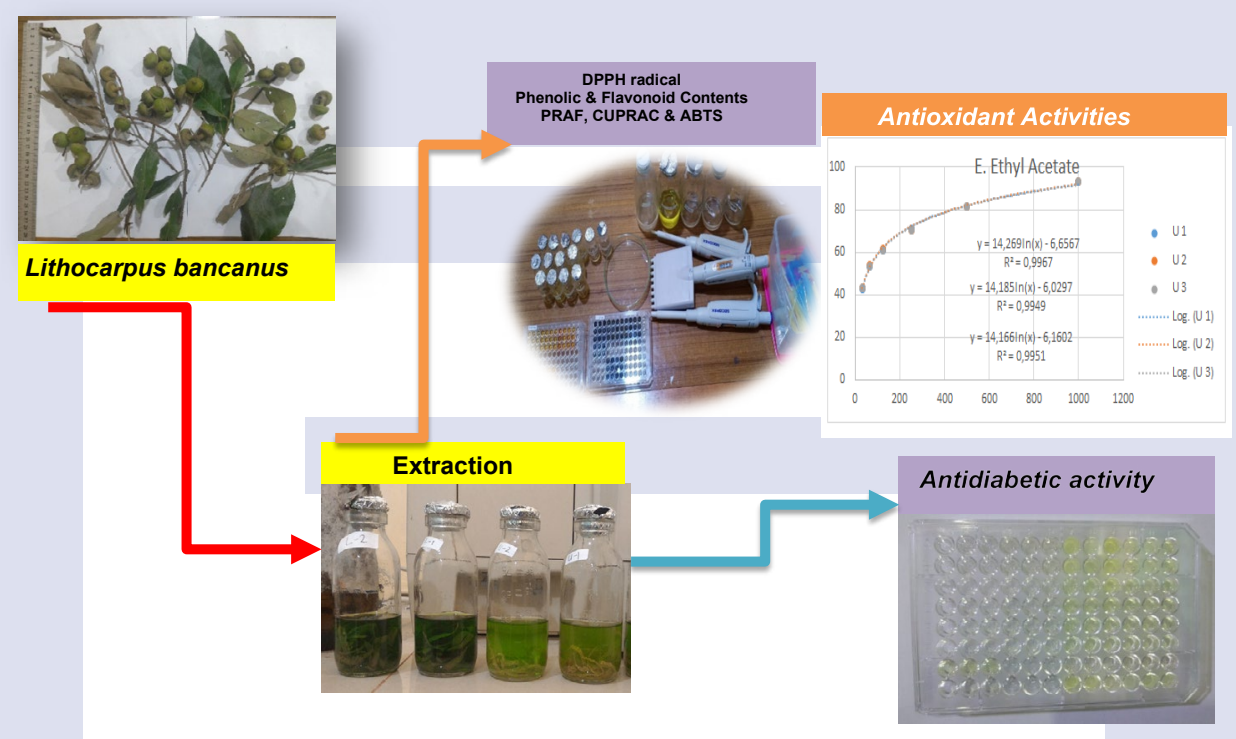

\section{ABOUT AUTHORS}

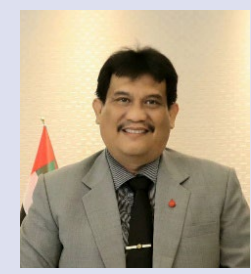

\section{Hilwan Yuda Teruna, Ph.D}

Senior Lecturer in Natural Products Chemistry at Universitas Riau, Pekanbaru - Indonesia.

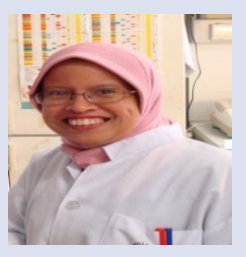

\section{Prof. Titania Tjandrawati Nugroho, Ph.D}

Professor in Biochemistry and Molecular Biology at Universitas Riau, Pekanbaru - Indonesia.
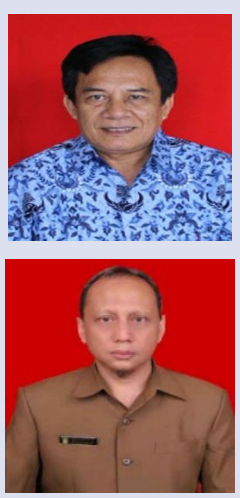

\section{Prof. Adel Zamri, Ph.D}

Professor in Organic Synthesis at Universitas Riau, Pekanbaru - Indonesia.

\section{Prof. Jasril Karim, Ph.D}

Professor in Organic Synthesis at Universitas Riau, Pekanbaru - Indonesia.

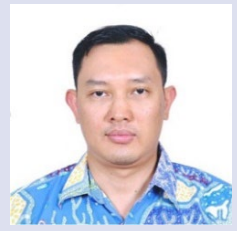

\section{Rudi Hendra, Ph.D}

Senior Lecturer in Natural Products Chemistry at Universitas Riau, Pekanbaru - Indonesia. 


\section{Yum Eriyanti, Ph.D}

Senior Lecturer in Organic Synthesis at Universitas Riau, Pekanbaru - Indonesia.

\section{Muhammad Almurdani, MS}

Doctoral Candidate in Department of Chemistry, Universitas Riau.

Cite this article: Almurdani M, Zamri A, Nugroho TT, Karim J, Eryanti Y, Hendra R, et al. Antioxidant and Antidiabetic Activities of Mempening (Lithocarpus bancanus) Leaves. Pharmacog J. 2020;12(2):328-34. 